\title{
Managerial Implementation of the Principal in Elementary School
}

\author{
by \\ Muhaimin ${ }^{1}$ \\ SDN 12 Selat Penuguan, Banyuasin, South Sumatera, Indonesia \\ Email: iminmuhaiminan@gmail.com \\ Bukman Lian \\ Universitas PGRI Palembang, Indonesia \\ Email:drbukmanlian@univpgri-palembang.ac.id, \\ Dessy Wardiah \\ Universitas PGRI Palembang, Indonesia \\ Email: dessywardiah77@gmail.com
}

\begin{abstract}
This study aimed at determining the managerial implementation of school principals at SD Negeri 24 Pulau Rimau. This research was conducted using a qualitative descriptive research approach. The subject is the school principal at SDN 24 Pulau Rimau. The informants are the school principal and teacher. Data collection techniques were (1) observation; (2) interview; and (3) documentation. The collected data is examined for the validity of the data, using triangulation, with verification and checking of the adequacy of the references. The results of this study were the ability of the managerial implementation of principals at SD Negeri 24 Pulau Rimau was very good seen from planning, organizing, directing, and supervising.
\end{abstract}

Keywords: Managerial Implementation, Principal, Primary School.

\section{Introduction:}

This study stems from the results of the National Accreditation Agency (BAN) assessment at SDN 24 Rimau, Banyuasin Regency based on the Decree on the determination of the results of BAP-S/M accreditation Number: 549/BAP-SM/TU/X/2015 with good accreditation scores (B). Whereas SDN 24 Pulau Rimau is located in a remote area (water area), which is precisely on Primary Road 14 RT 02, Karang Manunggal Village, Pulau Rimau, Banyuasin.

Table 1. SD Negeri 24 Pulau Rimau Accreditation Value

\begin{tabular}{|c|l|c|}
\hline No & \multicolumn{1}{|c|}{ Component } & Value \\
\hline 1 & Content Standard & 74 \\
\hline 2 & Process Standards & 85 \\
\hline 3 & Graduates Competency Standards & 70 \\
\hline 4 & Educator and Educational Staff Standards & 75 \\
\hline 5 & Infrastructure Standards & 67 \\
\hline 6 & Management Standards & 74 \\
\hline 7 & Financing Standards & 77 \\
\hline 8 & Educational Assessment Standards & 73 \\
\hline \multicolumn{2}{|c|}{ Final Score } & $\mathbf{7 5}$ \\
\hline
\end{tabular}

\footnotetext{
${ }^{1}$ Corresponding author
} 
From the accreditation table above, it can be seen that the standard for facilities and infrastructure is only 67. SD Negeri 24 Pulau Rimau, located in Karang Manunggal village, Pulau Rimau, Banyuasin, is an area that is difficult to reach by land transportation because its main transportation is water transportation, which is flanked by two major rivers are the Lalan River and Calik River and have limited social and economic facilities and infrastructure. In addition, Karang Manunggal village is directly adjacent to Galih Sari village, Lalan sub-district, Musi Banyuasin.

With the limited facilities and infrastructure available, it does not prevent the entire extended family of SD Negeri 24 Pulau Rimau from obtaining accreditation score B. All of that cannot be separated from the managerial implementation of school principal at SD Negeri 24 Pulau Rimau. In addition, the results of Muhaimin and Kristiawan's research (2019) inputs and suggestions given by school principals in the form of controlling are one of the extrinsic elements that can motivate teachers in remote areas to become professional teachers. Furthermore according to Kristiawan (2017) if teachers and staff have a high work spirit, are creative, are open, then one of the functions of the principal as an education leader to improve the quality of education will run well. This situation is determined by the form and nature of leadership by the principal, so that the teacher becomes professional. According to Harapan (2016) at the school level the determinant of education development is the principal. The school principal is included in the bureaucratic row related to the role of education, and acts as the implementer of all educational programs planned by the Central Government to the operational level at the school. Such education certainly requires management to achieve the objectives as expected. As stated in Law Number 20 of 2003 article 1 paragraph (1) states that Education is a conscious and planned effort to create an atmosphere of learning and learning process so that students actively develop their potential to have religious spiritual strength, self-control, personality, intelligence, noble character, and skills needed by himself, society, nation and country.

According to Murtiningsih and Lian (2017) to achieve the goals set, effort that can be done by the principal to influence, encourage, direct and mobilize educators, educational participants, guardians of students, and all related parties to work, and it means good principal leadership (Andriani et al, 2018; Irmayani et al, 2018; Renata et al, 2018; Khasanah et al, 2019; Tobari et al, 2018; Salwa et al, 2019; Wandasari et al, 2019; Apriana et al, 2019). The principal must have professional competence in all levels and types of education to able to carry out its functions properly. The competencies or abilities they possess are expected to strengthen or underlie their roles and responsibilities as administrators, managers, leaders and educational supervisors. Principals need administrative competence in management, leadership, and Controlling of education, because of their daily roles in managing and leading schools (Mantja, 2007). According to Fatah (2011) in the management process involved the main functions displayed by a manager/leader: planning, organizing, leadership and Controlling. The key to the success of schools in developing education is the principal. So the principal must be able to improve and improve the program at school.

Based on the background above, the researcher can provide insight and inspiration to study several matters relating to how the principal's managerial implementation and the role of the principal to improve the quality of education in SDN 24 Pulau Rimau.

\section{Methods:}

This study aimed at exploring intensive and in-depth knowledge about the managerial implementation of school principals and also the role of the principal in SD Negeri 24 Pulau 
Rimau. The approach used is qualitative research. Researchers try to uncover the symptoms of a particular tradition that is fundamentally dependent on human observations in their own age and relates to these people in their language and terminology (Moleong, 2012). Data was collected directly from research sources, SD Negeri 24 Pulau Rimau. This research is expected to be able to find and describe data comprehensively and intact about the managerial implementation of school principals and their role in educational institutions so as to improve school quality. Educational institutions which are the objects of this thesis research are SDN 24 Pulau Rimau. Sugiyono (2015) explains that qualitative research has the following characteristics; (a) has a natural setting as a source of direct data and the researcher is a key instrument; (b) is descriptive in nature, i.e. provides a specific situation and a descriptive view of the world; (c) pay more attention to the process than the product or product only; (d) tend to know data inductively; and (e) meaning is essential.

Furthermore Moleong (2012) explains that qualitative research is research that aims to understand phenomena about what is experienced by research subjects, for example behaviour, perception, motivation, actions, etc. holistically, and by means of descriptions in the form of words and language in a special natural context and by utilizing various scientific methods. Arikunto (2010) states that descriptive research is not intended to test certain hypotheses, but only describes "as is" about a variable, symptom or condition. In qualitative research, the researcher alone or with the help of others is the main data collector. The position of researchers in qualitative research is quite complicated. He is also a planner, executor of data collection, analysis, data interpreter, and in the end he becomes a reporter of the results of his research. Understanding the instrument or research tool here is right because it becomes everything from the whole research process (Ghony and Almanshur, 2014).

Based on the opinions and explanations above, basically the presence of researchers here as well as being an instrument is also an important factor in all of this research activity, because the depth and sharpness in analysing data depends on the researcher. Researchers as the main instrument enter the research space so that they can deal directly with informants and can naturally understand the reality that exists at SDN 24 Pulau Rimau.

\section{Results and Discussion:}

According to Mulyasa (2011) management in terminology is a process of developing collaborative activities of a group of people to achieve the stated educational goals. The process of controlling group activities includes planning, organizing, movement and Controlling as a process to turn vision into action. Management is a collaboration with and through others to achieve agreed upon goals systematically, efficiently, and effectively (Martoyo, 2002). In the implementation of such cooperation within an educational organization, a leader is needed to play a role in improving the quality of education, a school principal so that he will be responsible for the management of education that is directly related to the learning process. While schools as a system have core components consisting of inputs, processes and outputs. The three components are not separated from each other because it is a unified whole that is interrelated, which influences each other's needs and determines. School input is all input needed by the school for processing to obtain the expected output. Input can be categorized into two resource input and management or leadership input. The process of the on-going school is essentially the on-going learning, the occurrence of interaction between students and teachers supported by other devices as a principle of the learning process. 


\section{Planning in SD Negeri 24 Pulau Rimau:}

Planning is an activity aimed at answering what will be done and how it will do it to realize the goals that have been set upon at SD Negeri 24 Pulau Rimau, including the requirements needed to finance planned activities. This means planning is an activity to determine in advance what will be done, its procedures and methods of implementation to achieve the objectives at SD Negeri 24 Pulau Rimau. And is a preparation about what will be done to achieve the expected goals, in the form of a written document. What will be done, done, how, when and how much the estimated unit costs, as well as what results are expected. As in the opinion (Andang 2014) In determining the plan, it must be done carefully by conducting a systematic study in accordance with the conditions of the organization and the ability of resources while still referring to the vision and mission of the organization. According to Kristiawan (2017) the steps in the planning include; a) determine and formulate the objectives to be achieved; b) examine the problem or work to be performed; c) collecting data and information needed; d) determine the stages or series of actions; e) formulating how the problems will be solved and how the work will be solved.

SD Negeri 24 Pulau Rimau must be able to produce graduates who meet the required competencies to enter higher education levels. SD Negeri 24 Pulau Rimau must continue to innovate to improve the learning process and must improve classroom management. Providing, developing, managing and utilizing educational facilities and infrastructure and other resources so that it becomes an effective school. Schools must work together with all stakeholders to realize all the school goals above. Therefore, in order to achieve this, planning must be carried out for all that is to be done by making school work plans, so that they can know in detail the actions that must be taken so that the goals and objectives of the school can be achieved. according to Burhanuddin's (2005) opinion that basically planning is a systematic activity about what will be achieved, the activities that must be carried out, the steps, methods, implementation (energy) needed to carry out activities to achieve the objectives.

The results of an interview with the school principal on December 16, 2019 that said "As a school principal at the beginning of the year, of course there must be a meeting to formulate an education program that will be carried out over the next year so that we have a plan of activities to be carried out, and all of them need to be scheduled well". The initial step that must be taken to determine and explain the direction of education that the education provider wants to go to is to formulate the vision, mission and goals of the school. At SDN 24 Pulau Rimau the principal together with the teacher and the school committee must determine where the school will be directed, as long as it does not conflict with national education goals as stated in Law Number 20 of 2003 concerning National Education System. Expected conditions in a short time by clearly defined the school's vision, the desired condition or target to be achieved is related to the quality of education. While the mission is a description of the vision which is the main components that must be realized to achieve the vision that has been set. The goal is the stage between the initial conditions and the final destination whose formulation is contained in the vision and mission. Planning is essentially a process of making decisions about targets and ways to be carried out in the future in order to achieve the desired goals. The planning carried out by the Principal of SDN 24 Pulau Rimau is in accordance with its objectives and functions. Because in the world of education planning is the main thing to move to the next stage, so that the desired goals together can be achieved. Planning in schools should not deviate from the educational goals, because that is the goal that will become the basis of a plan. And when seen as a whole at SDN 24 Pulau Rimau has succeeded in making education program planning so that it becomes an effective school. This is in accordance with previous relevant research conducted by Bekti (2016). 


\section{Organizing in SD Negeri 24 Pulau Rimau:}

An organization needs to organize its members so that the goals of the organization can be achieved well. Organizing is the process of preparing an organizational structure in accordance with the goals of the organization, its resources, and the surrounding environment. The main aspect in the process of preparing an organizational structure is the grouping of work activities of an organization so that similar activities are interconnected and can be done together. According to Kristiawan (2017) organizing as a process of determining, grouping and regulating various activities needed to achieve goals, placing people in each of these activities, providing the necessary tools, assigning authority that is relatively delegated to each individual who will do these activities. Andang (2014) explains what steps need attention, including; 1) The tasks to be carried out must be determined well in order to achieve the objectives of an organization; 2) workload must be divided, whether the burden can be done individually or must be done with a group; 3 ) effectively and efficiently work with members must be combined; 4 in a harmonious whole, mechanisms for coordinating work must be established; 5) effectiveness must be maintained and enhanced by taking steps and monitoring.

The results of the interview with the school principal on December 16, 2019 that said "SDN 24 Rimau Island has a good organizational structure and organization of teachers, which was arranged at the beginning of the year meeting by structuring the organizational structure and division of teacher assignments. This school structure has a task and authority in accordance with their respective duties and functions". The division of labour is the breakdown of work tasks so that each individual in the organization is responsible for carrying out their duties. In this organization the headmaster has performed his duties and functions as an education manager. The principal of SD Negeri 24 Pulau Rimau assigns tasks and responsibilities to all teachers. Choose teachers who are competent and talented in their fields. Then give the assignment letter in the form of a Decree (SK) so that the teacher who is given the responsibility will work more in accordance with the main tasks and functions (duties) of each. This is in accordance with relevant research conducted by Faisal (2012).

\section{Actuating in SD Negeri 24 Pulau Rimau:}

Movement is defined as the process by which a manager guides and moves employees to achieve predetermined goals. There is a desire for others to follow their desires by using personal power or office power effectively in place for the long-term organization. The goal is that tasks can be completed properly. In essence the movement contains motivating activities contained in directing activities as a facility or means of directing the personnel in an organization. According to Baharudin (2010) actuating is the relationship between individual aspects caused by the relationship between subordinates to be able to understand and understand the division of work that is effective and efficient. Movement is closely related to predetermine planning. A school principal must be able to mobilize educators, teachers and other education personnel to carry out the intended plan. Therefore managers or principals are required to be able to communicate, provide guidance or advice, think creatively, initiative, improve quality, and provide stimulation to their subordinates. According to Kristiawan (2017) actuating is a very important part in the management process. Unlike the other three functions, mobilization is considered the essence of management because it deals specifically with people. In an educational institution, if there is only planning and organizing it is not enough. For that we need actions or movements that can cause action. The realization of planning and organizing is a function of mobilization. The mobilization 
carried out by the principal is an effort to direct or mobilize educators and educational staff and to utilize the available facilities and infrastructure to achieve the goals of education together. This function motivates the teacher to work seriously so that the goals of education can be achieved effectively. This function is very important to realize organizational goals.

The results of an interview with the school principal on December 16, 2019 said that as the headmaster of schools must be wise, they must always provide direction, motivation and coaching at meetings. Always remind function and obligation as a teacher, protect and protect all school members. Likewise with the principal of SD Negeri 24 Pulau Rimau, he set an example by applying high discipline and being active in carrying out tasks, especially teaching assignments, helping to solve problems experienced by teachers and students. Can communicate well with subordinates and actively participate in activities carried out by students, for example during scouting and sports activities. The principal must always encourage the entire board of teachers, and vice versa, dare to give and receive criticism and advice from anyone. In other words the principal must also be willing to accept input from his subordinates and his subordinates must also be willing to respond to the principal's orders. To carry out management implementation in schools there must be high cooperation and participation of school residents and the community, principals must have openness in management, principals must have a willingness to change, principals must be responsive to the needs and must communicate well. Because movement is a human relationship in leadership that binds subordinates to be willing to understand and contribute energy effectively and efficiently in achieving school goals. This is in accordance with relevant research conducted by Pawennary (2013).

\section{Controlling in SD Negeri 24 Pulau Rimau:}

Controlling is the process of monitoring and supervising activities to ensure these activities are carried out in accordance with what has been planned. Controlling is carried out to ensure that organizational and management objectives can be achieved. According to Burhanudin (2010) by carrying out supervisory work, it is expected to achieve the quality of the organization's products based on a predetermined plan, so that consumers or stakeholders become satisfied. According to Syafruddin (2005) the function of supervision is to observe and measure all activities and results achieved by comparing the standards seen in the previous plan. Supervision is a strategy to avoid deviations in terms of a rational approach to the existence of inputs, the amount and quality of materials, staff, money, equipment, facilities, and information, as well as supervision of scheduling activities and the accuracy of the implementation of organizational activities, while others are supervision of the desired product standard.

The results of an interview with the school principal on December 16, 2019 said that controlling and supervision is carried out every day, sometimes with spontaneity, or direct communication with the teacher. Some activities are regular, and are held every end of the month, semester and end of the year. The principal of SD Negeri 24 Pulau Rimau in the process of controlling is evaluating the performance of the teacher. This is done to determine whether a teacher has performed properly, both in the delivery of lesson programs, class administration, or delivery of material. By conducting good controlling, it can be seen how far the results have been achieved. Therefore Controlling is a function of the latter's management. This function is the process of carrying out the stated goals. Because the end of planning is the process carried out to get results. According to researchers, the principal of SD 24 Pulau Rimau is able to manage schools so that they become good schools. In relation to the managerial implementation of the school principal in SD Negeri 24 Pulau Rimau, the school principal is good enough to implement 
managerial well. With a leader who is able to manage the school they lead as a whole, the school will become an effective school. This is in accordance with relevant research conducted by Bekti (2016).

\section{Conclusion:}

The managerial implementation of the school principal in SD Negeri 24 Rimau in terms of planning has been very good. The school principal plans the vision, mission and goals of the school very well. In making programs, the school principal involves teachers, parents and other school pioneers. In terms of organization it is very good, according to the procedure, clear organizational structure, clear division of tasks, clear main tasks and functions and responsibilities given by making a letter of assignment and decree. All elements coordinate with one another so that the objectives to be achieved in SD Negeri 24 Pulau Rimau can run well. In terms of actuating also has been going well. With the existence of strong leadership, the process of high teaching and learning activities, safe and good school environment, effective management of education, high participation from the community, as well as good communication. In terms of controlling can be seen from the implementation of each procedure properly. By monitoring every semester with a predetermine schedule both from the education department and from the principal directly. The aim is to improve the quality of education, coaching teachers and evaluation controlling is also carried out by the relevant agencies.

\section{Acknowledgment:}

We would like to express our special thanks and gratitude to Rector Universitas PGRI Palembang, Director of Graduate Program and the principal of SD Negeri 24 Pulau Rimau for the permission given to us, and teachers of SD Negeri 24 Pulau Rimau who gave us the support to do this wonderful project. This project was funded independent. Secondly, we would also like to thank our friends in Management of Education Universitas PGRI Palembang who helped us a lot in finalizing this project within the limited time frame.

\section{References}

Andang. (2014). Manajemen dan Kepemimpinan Kepala Sekolah, Konsep, Strategi, Dan Inovasi Menuju Sekolah Efektif [Management and Leadership of School Principals, Concepts, Strategies and Innovations Towards Effective Schools]. Yogyakarta: Ar-Ruzz Media.

Andriani, S., Kesumawati, N., \& Kristiawan, M. (2018). The Influence of the Transformational Leadership and Work Motivation on Teachers Performance. International Journal of Scientific \& Technology Research, 7(7).

Apriana, D., Kristiawan, M., \& Wardiah, D. (2019). Headmaster's Competency In Preparing Vocational School Students For Entrepreneurship. International Journal of Scientific \& Technology Research, 8(8).

Arikunto, S. (2010). Manajemen Penelitian [ Research Management]. Jakarta: Bumi Aksara.

Baharuddin, M. M. (2010). Manajemen Pendidikan Islam [Islamic Education Management]. Malang: UIN Maliki Press 
BAP-S/M Nomor: 549/BAP-SM/TU/X/2015

Burhanuddin, Y. (2005). Administrasi Pendidikan [Education administration]. Bandung: CV Pustaka Setia.

Departemen Pendidikan Nasional. (2008). Kamus Besar Bahasa Indonesia [Indonesia Dictionary]. Jakarta: Balai Pustaka.

Departemen Pendidikan Nasional. (2003). Undang-undang RI Nomor 20 tahun 2003 tentang sistem pendidikan nasional.

Faisal, A. A. (2012). The Influence of the Principal's Managerial Ability on the Performance of Teachers of Public Elementary Schools in the Kotagede District of Yogyakarta. Yogyakarta: UNY.

Fatah, N. (2011). Landasan Manajemen Pendidikan [Platform for Educational Management]. Bandung: Remaja Rosdakarya.

Ghony, M. J., \& Almanshur, F. (2014). Metode Penelitian Kualitatif [Qualitative Research Methods]. Jakarta: Ar-Ruzz Media.

Harapan, E. (2016). Vision of School Principals as Drivers of Educational Quality. Palembang: JMKSP (Jurnal Manajemen, Kepemimpinan dan Supervisi Pendidikan) 1(2) 133-145

Irmayani, H., Wardiah, D., \& Kristiawan, M. (2018). The Strategy of SD Pusri In Improving Educational Quality. International Journal of Scientific \& Technology Research, 7(7).

Khasanah, U., Kristiawan, M., \& Tobari. (2019). The Implementation of Principals' Academic Supervision In Improving Teachers' Professionalism in the State Primary Schools. International Journal of Scientific \& Technology Research, 8(8).

Kristiawan, M. (2017). Manajemen Pendidikan [Education Management]. Yogyakarta: Deepublish.

Mantja, W. (2007). Profesionalisasi Tenaga Kependidikan:Manajemen Pendidikan dan Supervisi Pengajaran [Professionalisation of Education Personnel: Management of Education and Teaching Supervision]. Malang: Elang Mas.

Martoyo. (2002). Manajemen Sumber Daya Manusia Kebijakan Kinerja Karyawan [Human Resource Management Employee Performance Policy]. Yogyakarta: BPFE.

Moleong, L. J. (2012). Metodologi Penelitian Kualitatif [Qualitative Research Methodology]. Bandung : Remaja Rosdakarya.

Muhaimin, M., \& Kristiawan, M. (2019, February). Resistance of Teachers Teaching In Remote Areas. In prosiding of national seminar of postgraduate program, PGRI palembang university. 
Mulyasa, E. (2011). Menjadi Kepala Sekolah Profesional [Become a Professional Principal]. Bandung: Remaja Rosdakarya.

Murtiningsih \& Lian, B. (2017). Principal Decision-Making Process Against the Improvement of the Performance of Junior High School Teachers. Palembang: JMKSP JMKSP (Jurnal Manajemen, Kepemimpinan dan Supervisi Pendidikan) 2(1) 87-96.

Pawennary, D. F. (2013). Managerial Competence Principal of Junior High Schools in Banguntapan District, Bantul Regency. Yogyakarta: Yogyakarta State University.

Renata, R., Wardiah, D., \& Kristiawan, M. (2018). The Influence of Headmaster's Supervision and Achievement Motivation on Effective Teachers. International Journal of Scientific \& Technology Research, 7(4).

Salwa., Kristiawan, M., \& Lian, B. (2019). The Effect of Academic Qualification, Work Experience and Work Motivation towards Primary School Principal Performance. International Journal of Scientific \& Technology Research, 8(8).

Sugiyono. (2015). Metode Penelitian Kuantitatif, Kualitatif dan R\&D [Quantitative, Qualitative, and R\&D Research Methods]. Bandung: Alfabeta.

Syafruddin. (2005). Manajemen Lembaga Pendidikan Islam [Management of Islamic Education Institutions]. Ciputat: Ciputat Press.

Tobari., Kristiawan, M., \& Asvio, N. (2018). The Strategy of Headmaster on Upgrading Educational Quality In Asean Economic Community (AEC) Era. International Journal of Scientific \& Technology Research, 7(4).

Wandasari, Y., Kristiawan, M., \& Arafat, Y. (2019). Policy Evaluation of School's Literacy Movement on Improving Discipline of State High School Students. International Journal of Scientific \& Technology Research, 8(4). 